\title{
Forms of Potassium and their Distribution under Prominent Cropping Systems of Chittoor District of Andhra Pradesh, India
}

\author{
G.R. Charankumar and V. Munaswamy \\ Department of Soil Science and Agricultural Chemistry, S. V. Agricultural College, Tirupati-517 502, India \\ E-mail: charangrkumar@gmail.com
}

\begin{abstract}
An investigation was carried out to assess distribution of forms of potassium in soils and seven prominent cropping systems from Chittoor district of Andhra Pradesh viz., Groundnut + Redgram, Groundnut-Groundnut, Groundnut monocropping, Redgram monocropping, Sugarcane monocropping, Paddy-Groundnut and Bajra-Groundnut. The highest mean available K was recorded under groundnut + redgram intercropping system (126.41 $\left.\mathrm{mg} \mathrm{kg}^{-1}\right)$ in surface soils, while in sub-surface soils under groundnut monocropping system $\left(89.32 \mathrm{mg} \mathrm{kg}{ }^{-1}\right)$, water soluble $\mathrm{K}$ in surface soils under bajra-groundnut cropping system $\left(38.70 \mathrm{mg} \mathrm{kg}^{-1}\right)$, while in sub-surface soils under groundnut + redgram intercropping system $\left(23.29 \mathrm{mg} \mathrm{kg}^{-1}\right)$, exchangeable $\mathrm{K}$ under groundnut monocropping system in surface soils $\left(102.63 \mathrm{mg} \mathrm{kg}{ }^{-1}\right)$ and in subsurface soils (72.17 mg kg ${ }^{-1}$ ), non-exchangeable $\mathrm{K}$ under paddy-groundnut cropping system (517.83 $\left.\mathrm{mg} \mathrm{kg}^{-1}\right)$, while in sub-surface under bajra-groundnut cropping system $\left(475.20 \mathrm{mg} \mathrm{kg}^{-1}\right)$. The mean lattice $\mathrm{K}$ and total $\mathrm{K}$ were under redgram monocropping system in surface soils (40313.16 mg kg - $^{-1}$ and $40794 \mathrm{mg} \mathrm{kg}^{-1}$, respectively), while in sub-surface soils under groundnut+redgram intercropping system (35802.72 mg $\mathrm{kg}^{-1}$ and $36248 \mathrm{mg} \mathrm{kg}^{-1}$, respectively). The different forms of potassium were positively and significantly correlated among themselves with each other in soils of indicating dynamic equilibrium among different forms $\mathrm{K}$.
\end{abstract}

Keywords: Available K, Non-exchangeable K, Lattice K, Total K, Cropping systems

Potassium is third main pillar of balanced fertilizer use after nitrogen and phosphorus. It plays number of vital and crucial physiological roles in plant growth and development, but its importance is often under estimated, as it doesn't produce rapid growth like nitrogen. Among the essential plant nutrients, potassium $(\mathrm{K})$ assumes greater significance because it is needed in comparatively larger amounts by plants and besides increasing the yield and immensely enhances the crop produce quality (Srinivasrao et al 2011). Potassium is neglected nutrient in an intensive agricultural production because of the general conception that Indian soils are rich in native- $K$ resulted from the exclusion of potassium in balanced nutrition lead to the mining of soil reserve $\mathrm{K}$. Exclusion of potassium in balanced nutrition leads to the mining of soil reserve $\mathrm{K}$. The potassium in soil is enigmatic nutrient as its availability is governed by parent material, degree of weathering, application of fertilizers and manures, and losses due to crop removal, erosion and leaching (Lalitha and Dakshinamoorthy 2014). Crops response to added potassic fertilizers is more associated with shift in the dynamic equilibrium within the forms of $\mathrm{K}$ than quantity of available K in liable pool (Kishore et al 2020). The knowledge on the potassium forms in soils is crucial since it provides insight into the potassium distribution within soils. It can indicate the depletion as well as accumulation pattern of potassium in soil. Information on forms of potassium and their distribution in soil will help in assessing the long term potassium availability to crops. Keeping this in view, the present investigation was undertaken to study the distribution and dynamics of $\mathrm{K}$ under prominent cropping systems of Chittoor district of Andhra Pradesh.

\section{MATERIAL AND METHODS}

An investigation was carried out in S. V. Agricultural College, Tirupati, during 2019 to assess the forms of potassium in soils of Chittoor district of Andhra Pradesh, India, extending between $12^{\circ} 37^{\prime \prime}$ to $14^{\circ} 8^{\prime \prime}$ North latitude and $78^{\circ} 33^{\prime \prime}$ to $79^{\circ} 55^{\prime \prime}$ East longitude. The district experiences both southwest monsoon and north east monsoon with mean annual rainfall of $934.0 \mathrm{~mm}$. Seven prominent cropping systems of which six are legume based cropping systems of the district viz., Groundnut + Redgram, Groundnut Groundnut, Groundnut mono cropping, Redgram mono cropping, Sugarcane mono cropping, Paddy - Groundnut and Bajra - Groundnut were selected and five soil samples from each cropping system at $0-15 \mathrm{~cm}$ and $15-30 \mathrm{~cm}$ depths were collected air-dried, ground and sieved through a $2 \mathrm{~mm}$ stainless steel sieve and stored in cloth bags. The soil samples used for analysing various forms of potassium by employing standard methods of analyses as detailed in Table 
1. Simple correlation coefficients ('r') were also worked out for relationships among potassium forms using Statistical Package for Social Sciences (SPSS) software.

\section{RESULTS AND DISCUSSION}

Available K: The available $\mathrm{K}$ content of surface soils varied from $36.20 \mathrm{mg} \mathrm{kg}^{-1}$ in Paddy-Groundnut cropping system to $139.30 \mathrm{~g} \mathrm{~kg} \mathrm{k}^{-1}$ in Groundnut+Redgram intercropping system with mean of 40.99 and $126.41 \mathrm{mg} \mathrm{kg}^{-1}$, respectively and contribution of available $\mathrm{K}$ to total $\mathrm{K}$ ranged from 0.13 to 0.39 per cent. In sub-surface soils, available $\mathrm{K}$ content varied from $25.55 \mathrm{mg} \mathrm{kg}^{-1}$ in Paddy-Groundnut cropping system to 100.70 $\mathrm{mg} \mathrm{kg}^{-1}$ in Groundnut monocropping system with mean 31.69 and $89.32 \mathrm{mg} \mathrm{kg}^{-1}$, respectively (Table 2). The contribution of available $\mathrm{K}$ to total $\mathrm{K}$ ranged from 0.13 per cent in PaddyGroundnut and Sugarcane mono cropping system to 0.29 per cent in Groundnut mono cropping system. The highest available $\mathrm{K}$ was observed in soils of Groundnut+Redgram intercropping system and Groundnut monocropping system in surface and sub-surface soils, respectively which might be due to application of potassic fertilizers in this cropping system and also may be due to the presence of clay rich minerals like illite and kaolinite. Harsha and Jagadeesh (2017) observed lowest available K was recorded in PaddyGroundnut cropping system in both surface and sub-surface soils, which might be due to continuous removal of potassium by the Paddy-Groundnut cropping system. The highest available potassium was observed in surface soils than in sub-surface soils in all cropping systems, which might be attributed to application of potassic fertilizers in the previous crop as reported by Padhan et al (2015).

Water soluble K: The water soluble $\mathrm{K}$ content of surface soils varied from $6.55 \mathrm{mg} \mathrm{kg}^{-1}$ in Paddy-Groundnut cropping system to $41.20 \mathrm{mg} \mathrm{kg}^{-1}$ in Bajra-Groundnut cropping system with mean 7.93 and $38.70 \mathrm{mg} \mathrm{kg}^{-1}$, respectively. The water soluble $\mathrm{K}$ contributed least to total $\mathrm{K}$ and ranged from 0.02 to 0.12 . In sub-surface soils water soluble $K$ content varied from $2.14 \mathrm{mg} \mathrm{kg}^{-1}$ in Paddy-Groundnut cropping system to 25.85 $\mathrm{mg} \mathrm{kg}^{-1}$ in Groundnut + Redgram intercropping system with mean values of 7.19 and $23.29 \mathrm{mg} \mathrm{kg}^{-1}$, respectively (Table
2). Contribution of water soluble $K$ to total $K$ ranged from 0.02 to 0.06 per cent. The highest water soluble $K$ was observed in soils of bajra-Groundnut cropping system and Groundnut + Redgram intercropping system in surface and sub-surface soils, respectively. The similar trend was reported by Lakaria et al (2012) which might be due to external application of water soluble fertilizers under intensive farming system and lowest was observed in Paddy-Groundnut cropping system and Sugarcane monocropping system in surface and subsurface soils, respectively which might be due to more uptake or utilization water soluble $\mathrm{K}$ fertilizers. Further in all cropping systems, surface soils had higher water soluble $\mathrm{K}$ than subsurface soils, which may be attributable to exposure of $\mathrm{K}$ bearing minerals to weathering, or upward translocation of $\mathrm{K}$ from subsurface layers through capillary rise, or due to $K$ addition via plant residues, manures, and chemical fertilizers (Rao et al 2013).

Exchangeable K: The exchangeable $\mathrm{K}$ content of surface soils varied from $29.50 \mathrm{mg} \mathrm{kg}^{-1}$ in Paddy-Groundnut cropping system to $111.80 \mathrm{mg} \mathrm{kg}^{-1}$ in Groundnut monocropping system with mean values of 33.06 and $102.63 \mathrm{mg} \mathrm{kg}^{-1}$, respectively. The exchangeable $\mathrm{K}$ contribution to total $\mathrm{K}$ ranged from 0.10 to 0.31 per cent. In sub-surface soils exchangeable $K$ content varied from $23.08 \mathrm{mg} \mathrm{kg}^{-1}$ in Paddy-Groundnut cropping system to $81.20 \mathrm{mg} \mathrm{kg}^{-1}$ in Groundnut monocropping system with mean 24.50 and $72.17 \mathrm{mg} \mathrm{kg}^{-1}$, respectively (Table 2). This fraction contributed 0.09 to 0.23 per cent to total K. The highest exchangeable $\mathrm{K}$ was observed in soils of Groundnut monocropping system in both surface and sub-surface soils, which might be due to application of fertilizers might resulted in higher buildup of $K$ in these soils or lower utilization of applied $\mathrm{K}$ and however, lowest exchangeable $\mathrm{K}$ was observed in Paddy-Groundnut cropping system at both depths. Highest exchangeable $\mathrm{K}$ was observed in surface soils than in subsurface soils in all cropping systems, which might be attributed to continuous application of fertilizers to surfaces layers only and also addition of higher root biomass. These results were similar to the findings of Lungmuana et al (2014).

Non-exchangeable K: The fraction of non-exchangeable $\mathrm{K}$ content in surface soils varied from $275.05 \mathrm{mg} \mathrm{kg}^{-1}$ in

Table 1. Analytical methods followed during chemical analysis

\begin{tabular}{lll}
\hline Properties & Methodology & Reference \\
\hline Available potassium & Neutral $1 \mathrm{~N} \mathrm{NH}_{4} \mathrm{OAC}$ extraction & Jackson (1973) \\
Forms of potassium & Flame photometry & Jackson (1973) \\
Water soluble K & $1: 5$ Soil water suspension & Wood and De Turk (1941) \\
Exchangeable K & Available K - Water soluble K & Wiklander (1954) \\
Non-exchangeable K & Boiling $1 \mathrm{~N}$ Nitric acid extraction & Pratt (1965) \\
\hline
\end{tabular}


Groundnut monocropping system to $581.55 \mathrm{mg} \mathrm{kg}^{-1}$ in PaddyGroundnut cropping system with mean 309.96 and 517.83 $\mathrm{mg} \mathrm{kg}{ }^{-1}$, respectively. This fraction contribution to total $\mathrm{K}$ ranged from 0.82 to 1.93 per cent. In sub-surface soils, nonexchangeable $\mathrm{K}$ content varied from $227.25 \mathrm{mg} \mathrm{kg}^{-1}$ in Groundnut monocropping system to $495.90 \mathrm{mg} \mathrm{kg}^{-1}$ in bajraGroundnut cropping system with mean values of 247.96 and $475.20 \mathrm{mg} \mathrm{kg}^{-1}$, respectively (Table 2 ). Per cent contribution of non-exchangeable $\mathrm{K}$ to total $\mathrm{K}$ varied between 0.81 and 1.84. The highest non-exchangeable $\mathrm{K}$ was observed in soils of Paddy-Groundnut cropping system and bajra-Groundnut in surface and sub-surface soils, respectively which might be due to conversion of added water soluble $\mathrm{K}$ into nonexchangeable forms, increased fixation induced by high levels of $\mathrm{K}$ fertilization and the successive application which might have decreased utilization of non-exchangeable $\mathrm{K}$ leading to its accumulation (Rout et al 2017) and lowest nonexchangeable $\mathrm{K}$ was observed in Groundnut monocropping system at both depths, which might be due to the fact that more removal of exchangeable $\mathrm{K}$ by crop in order to replenish decreased exchangeable $\mathrm{K}$, non-exchangeable $\mathrm{K}$ was resealed and thus dynamic equilibrium was maintained (Tomar et al 2017). The highest non-exchangeable $\mathrm{K}$ was observed in surface soils than in sub-surface soils in all cropping systems, except in bajra-Groundnut cropping system. Similar results reported by Jassal et al (2012), Kumari and Nisha (2014).

Lattice K: The lattice $\mathrm{K}$ content of surface soils varied from $16716.30 \mathrm{mg} \mathrm{kg}^{-1}$ in Groundnut-Groundnut cropping system to $42529.80 \mathrm{mg} \mathrm{kg}^{-1}$ in Redgram monocropping system with mean value of 19866.02 and $40313.16 \mathrm{mg} \mathrm{kg}^{-1}$, respectively. Major portion of total $\mathrm{K}$ comprised of this fraction and contribution varied from 97.79 to 98.85 per cent. In subsurface soils lattice $\mathrm{K}$ content varied from $20041.20 \mathrm{mg} \mathrm{kg}^{-1}$ in Paddy-Groundnut cropping system to $38496.60 \mathrm{mg} \mathrm{kg}^{-1}$ in Groundnut+Redgram intercropping system with mean 23618.92 and $35802.72 \mathrm{mg} \mathrm{kg}^{-1}$, respectively (Table 2). Per cent contribution of lattice $\mathrm{K}$ to total $\mathrm{K}$ ranged from 98.03 to 98.91. The highest lattice $K$ was observed in soils of Redgram monocropping system and Groundnut+Redgram intercropping system in surface and sub-surface soils, respectively which might be due to higher content of mica and feldspars in coarse fractions and illite mineral in clay (Elbaalawy et al 2016) and lowest lattice $\mathrm{K}$ was observed in Groundnut-Groundnut cropping system and PaddyGroundnut cropping system in surface and sub-surface soils, respectively which might be due to nature of parent material from which soils were developed. The data further revealed

Table 2. Distribution of different forms of potassium under different cropping systems

\begin{tabular}{|c|c|c|c|c|c|c|c|c|c|c|c|c|}
\hline \multirow[t]{2}{*}{$\begin{array}{l}\text { Cropping } \\
\text { systems }\end{array}$} & & \multicolumn{2}{|c|}{$\begin{array}{c}\text { Available K } \\
\left(\mathrm{mg} \mathrm{kg}^{-1}\right)\end{array}$} & \multicolumn{2}{|c|}{$\begin{array}{l}\text { Water soluble } \mathrm{K} \\
\left(\mathrm{mg} \mathrm{kg}^{-1}\right)\end{array}$} & \multicolumn{2}{|c|}{$\begin{array}{l}\text { Exchangeable } \mathrm{K} \\
\left(\mathrm{mg} \mathrm{kg}^{-1}\right)\end{array}$} & \multicolumn{2}{|c|}{$\begin{array}{c}\text { Non- } \\
\text { exchangeable } \mathrm{K} \\
\left(\mathrm{mg} \mathrm{kg}^{-1}\right)\end{array}$} & $\begin{array}{l}\text { Lattice K } \\
\left(\mathrm{mg} \mathrm{kg}^{-1}\right)\end{array}$ & \multicolumn{2}{|c|}{$\begin{array}{c}\text { Total K } \\
\left(\mathrm{mg} \mathrm{kg}^{-1}\right)\end{array}$} \\
\hline & & $0-15$ & $15-30 \mathrm{~cm}$ & -15 & $5-30 \mathrm{~cm}$ & $0-15 c$ & $15-30 \mathrm{~cm}$ & $0-15$ & $15-30 \mathrm{~cm}$ & $0-15 \mathrm{~cm} 15-30 \mathrm{~cm}$ & $0-15 \mathrm{~cm}$ & $-30 \mathrm{~cm}$ \\
\hline \multirow{3}{*}{$\begin{array}{l}\text { Groundnut + } \\
\text { Redgram }\end{array}$} & Min. & 113.20 & 50.15 & 21.10 & 21.35 & 92.10 & 28.80 & 498.20 & 373.55 & 29128.6031614 .70 & 29740 & 32050 \\
\hline & Max. & 139.30 & 60.00 & 30.85 & 25.85 & 108.45 & 34.45 & 539.10 & 413.40 & 35250.3038496 .60 & 35910 & 38970 \\
\hline & Mean & 126.41 & 55.67 & 25.85 & 23.29 & 100.56 & 32.38 & 514.99 & 389.61 & 31994.6035802 .72 & 32636 & 36248 \\
\hline \multirow{3}{*}{$\begin{array}{l}\text { Groundnut - } \\
\text { Groundnut }\end{array}$} & Min. & 50.55 & 41.35 & 9.90 & 11.45 & 40.20 & 28.55 & 350.55 & 280.05 & 16716.3029594 .40 & 17190 & 29930 \\
\hline & Max. & 61.80 & 48.05 & 18.40 & 14.10 & 45.65 & 36.25 & 418.00 & 330.50 & 22027.4033637 .40 & 22460 & 33970 \\
\hline & Mean & 56.67 & 45.55 & 13.06 & 12.69 & 43.61 & 32.86 & 391.31 & 302.37 & 19866.0231608 .08 & 20314 & 31956 \\
\hline \multirow{3}{*}{$\begin{array}{l}\text { Groundnut } \\
\text { monocropping }\end{array}$} & Min. & 112.30 & 81.65 & 19.85 & 16.15 & 92.45 & 50 & 275.05 & 227.25 & 32407.40 & 32810 & 28910 \\
\hline & Max. & 136.35 & 100.70 & 25.40 & 19.50 & 111.80 & 81.20 & 336.35 & 271.70 & 41971.5032537 .90 & 42410 & 32890 \\
\hline & Mean & 125.46 & 89.32 & 22.83 & 17.15 & 102.63 & 72.17 & 309.96 & 247.96 & 37398.5830412 .72 & 37834 & 30750 \\
\hline \multirow{3}{*}{$\begin{array}{l}\text { Redgram } \\
\text { Monocropping }\end{array}$} & Min. & 61.25 & 59.75 & 10.85 & 10.45 & 50.40 & 47.60 & 398.70 & 338.15 & 38423.6029457 .50 & 38920 & 29900 \\
\hline & Max. & 78.30 & 72.95 & 18.50 & 15.25 & 60.35 & 57.70 & 433.05 & 422.55 & 42529.8035485 .80 & 42990 & 35890 \\
\hline & Mean & 69.00 & 64.71 & 14.89 & 13.05 & 54.11 & 51.66 & 411.84 & 377.23 & 40313.1632316 .06 & 40794 & 32758 \\
\hline \multirow{3}{*}{$\begin{array}{l}\text { Sugarcane } \\
\text { Monocropping }\end{array}$} & Min. & 58.80 & 39.55 & 7.10 & 5.55 & 51.70 & 32.30 & 355.65 & 270.95 & 29948.0029555 .70 & 30370 & 29900 \\
\hline & Max. & 82.95 & 47.40 & 9.80 & 7.25 & 74.60 & 41.65 & 396.15 & 452.00 & 38146.6035720 .60 & 38610 & 36220 \\
\hline & Mean & 68.63 & 43.30 & 8.56 & 6.06 & 60.07 & 37.24 & 385.75 & 358.18 & 35083.6232606 .52 & 35538 & 33008 \\
\hline \multirow{3}{*}{$\begin{array}{l}\text { Paddy - } \\
\text { Groundnut }\end{array}$} & Min. & 36.20 & 25.55 & 6.55 & 2.14 & 29.50 & 23.08 & 444.50 & 381.40 & 28289.3020041 .20 & 28890 & 20450 \\
\hline & Max. & 45.65 & 36.90 & 8.80 & 5.65 & 36.85 & 31.69 & 581.55 & 489.80 & 32937.2027868 .20 & 33520 & 28350 \\
\hline & Mean & 40.99 & 31.69 & 7.93 & 7.19 & 33.06 & 24.50 & 517.83 & 443.39 & 31087.1823618 .92 & 31646 & 24094 \\
\hline \multirow{3}{*}{$\begin{array}{l}\text { Bajra - } \\
\text { Groundnut }\end{array}$} & Min. & 101.95 & 76.70 & 35.60 & 10.85 & 62.85 & 62.05 & 396.80 & 449.25 & 28137.6030333 .90 & 28670 & 30910 \\
\hline & Max. & 115.25 & 94.00 & 41.20 & 17.30 & 76.10 & 78.10 & 431.95 & 495.90 & 36630.1034305 .50 & 37150 & 34870 \\
\hline & Mean & 108.50 & 82.86 & 38.70 & 14.66 & 69.80 & 68.20 & 414.30 & 475.20 & 32959.2032021 .94 & 33482 & 32580 \\
\hline
\end{tabular}


that in general highest lattice $\mathrm{K}$ was observed in surface soils than in sub-surface soils in all cropping systems, which on contrary with findings of Sawarkar et al (2013). However, higher values of lattice $\mathrm{K}$ in sub-surface soils was observed in Groundnut+Redgram intercropping system and GroundnutGroundnut cropping system which might be due to fact that these soils may be rich micaceous parent material (Kundu et al 2014)

Total K: The total K content of surface soils varied from 17190 $\mathrm{mg} \mathrm{kg}^{-1}$ in Groundnut-Groundnut cropping system to 42990 $\mathrm{mg} \mathrm{kg}^{-1}$ in Redgram monocropping system with mean of 20314 and $40794 \mathrm{mg} \mathrm{kg}^{-1}$, respectively. In sub-surface soils total $\mathrm{K}$ content varied from $20450 \mathrm{mg} \mathrm{kg}^{-1}$ in Paddy-Groundnut cropping system to $38970 \mathrm{mg} \mathrm{kg}^{-1}$ in Groundnut+Redgram intercropping system with mean 24094 and $36248 \mathrm{mg} \mathrm{kg}^{-1}$, respectively (Table 2 ). The highest total $\mathrm{K}$ was recorded in soils of Redgram monocropping system and Groundnut+Redgram cropping system in surface and subsurface soils, respectively which might be due to presence of sufficient quantity of potash bearing primary minerals like feldspar and mica and it seemed to be directly related with clay and organic matter content of these soils (Saini and Grewal, 2014) and lowest total K was in GroundnutGroundnut cropping system and Paddy-Groundnut cropping system in surface and sub-surface soils, respectively. The data further revealed that highest total $\mathrm{K}$ was observed in surface soils than in sub-surface soils in all cropping systems, except in Groundnut+Redgram intercropping system and Groundnut-Groundnut cropping system, which might be attributed to weathering of primary $\mathrm{K}$ bearing minerals.

Correlation among various forms of potassium: In surface soils, available $\mathrm{K}$ was highly and significantly correlated with water soluble $\mathrm{K}$, exchangeable $\mathrm{K}$ (nonexchangeable lattice $\mathrm{K}$ and total $\mathrm{K}$ (Table 3 ). Similar results were reported by Jadhao et al. (2018) indicating dynamic equilibrium among all the forms of potassium under sorghum-wheat cropping system. Water soluble $\mathrm{K}$ was highly and significantly correlated with available exchangeable $\mathrm{K}$ and non-exchangeable $\mathrm{K}$ (Table 3 ). Similar results reported by Dhakad et al (2017) observed similar trend in soils of Gwalior district of Madhya Pradesh. The good correlation between water-soluble $\mathrm{K}$ and other potassium forms signifies that water-soluble $\mathrm{K}$ is regulated by other forms of $\mathrm{K}$ such as non-exchangeable $\mathrm{K}$ and total $\mathrm{K}$. Exchangeable $\mathrm{K}$ positively and significantly correlated with available $\mathrm{K}$ water soluble $\mathrm{K}$, non-exchangeable $\mathrm{K}$, lattice $\mathrm{K}$ and total $\mathrm{K}$ (Table 3). These results are on par with results of Kundu et al (2014) in soils of West Bengal. Non-exchangeable $\mathrm{K}$ was positively and significantly correlated with lattice $\mathrm{K}$ and total $\mathrm{K}$. Lattice $\mathrm{K}$ was highly and significantly correlated with total K. High degree of correlation was noted among lattice $\mathrm{K}$ and total K. Similar results were reported by Mali et al (2016) under soils of soybean growing farmer's field in vertisols.

In sub-surface soils, available $\mathrm{K}$ was highly and significantly correlated with water soluble $\mathrm{K}$, exchangeable $\mathrm{K}$, lattice $\mathrm{K}$ and total $\mathrm{K}$. Water soluble $\mathrm{K}$ was highly and significantly correlated with available $\mathrm{K}$, lattice $\mathrm{K}$ and total $\mathrm{K}$ (Table 4). Similar results were reported by Jadhao et al

Table 3. Correlation among different forms of potassium in surface soils under different cropping systems

\begin{tabular}{lccccc}
\hline & Avl-K & WS-K & EX-K & NEX-K & Lattice-K \\
\hline Avl-K & 1 & & & & \\
WS-K & $0.779^{* *}$ & 1 & & & \\
EX-K & $0.963^{* *}$ & $0.592^{* *}$ & 1 & & \\
NEX-K & $0.837^{* *}$ & $0.444^{* *}$ & $0.893^{* *}$ & 1 & 1 \\
Lattice-K & $0.361^{*}$ & 0.208 & $0.376^{*}$ & $0.360^{*}$ & $0.999^{* *}$ \\
Total-K & $0.374^{*}$ & 0.216 & $0.390^{*}$ & $0.374^{*}$ & 1 \\
\hline
\end{tabular}

** Correlation is significant at the 0.01 level (2-tailed); ${ }^{*}$ Correlation is significant at the 0.05 level (2-tailed); $N=35$

Table 4. Correlation among different forms of potassium in sub-surface soils under different cropping systems

\begin{tabular}{lccccc}
\hline & Avl-K & WS-K & EX-K & NEX-K & Lattice-K \\
\hline Avl-K & 1 & & & & \\
WS-K & $0.541^{* *}$ & 1 & & & \\
EX-K & $0.963^{* *}$ & 0.298 & 1 & 1 & 1 \\
NEX-K & 0.080 & 0.013 & 0.088 & $0.442^{* *}$ & 1 \\
Lattice-K & $0.336^{*}$ & $0.506^{* *}$ & 0.225 & $0.437^{* *}$ & $0.969^{* *}$ \\
Total-K & $0.338^{*}$ & $0.496^{* *}$ & 0.233 & 1 \\
\hline
\end{tabular}

${ }^{* *}$ Correlation is significant at the 0.01 level (2-tailed); * Correlation is significant at the 0.05 level (2-tailed); $N=35$ 
(2018). Exchangeable $\mathrm{K}$ was highly and significantly correlated with available $\mathrm{K}$ and these findings were in accordance with Jassal et al (2012). Non-exchangeable K was highly and significantly correlated with lattice $K$ and total $\mathrm{K}$. Lattice $\mathrm{K}$ was highly and significantly correlated with available $\mathrm{K}$ water soluble $\mathrm{K}$ and non-exchangeable $\mathrm{K}$ and total $\mathrm{K}$ (Table 4). Total $\mathrm{K}$ was highly and significantly correlated with available $\mathrm{K}$; water soluble $\mathrm{K}$, nonexchangeable $\mathrm{K}$ and lattice $\mathrm{K}$. Similar results were reported by Kundu et al (2014).

\section{CONCLUSIONS}

Soil $\mathrm{K}$ fractions in all cropping systems were in the order of total $\mathrm{K}>$ lattice $\mathrm{K}>$ non-exchangeable $\mathrm{K}>$ available $\mathrm{K}>$ exchangeable $\mathrm{K}>$ water soluble $\mathrm{K}$. Under rainfed conditions all the forms of potassium were highest in groundnut+redgram intercropping system followed by groundnut monocropping system and redgram monocropping system while under irrigated conditions all the forms of potassium were highest in bajra-groundnut cropping system followed by sugarcane monocropping system, groundnut-groundnut cropping system and paddy-groundnut cropping system. The different forms of $\mathrm{K}$ were positively and significantly correlated with each other in soils at both layers indicating dynamic equilibrium among different forms.

\section{REFERENCES}

Dhakad H, Yadav SS, Jamra S, Arya V, Sharma, K and Gaur D 2017. Status and distribution of different forms of potassium in soils of Gwalior district (M.P.). International Journal of Chemical Studies 5(5): 161-164.

Elbaalawy AM, Benbi DK and Benipal DS 2016. Potassium forms in relation to clay mineralogy and other soil properties in different agro-ecological sub-regions of Northern India. Agricultural Research Journal 53(2): 200-206.

Harsha BR and Jagadeesh BR 2017. Forms and distribution of potassium in selected maize growing soils of Haveri district of Karnataka, India. International Journal of Current Microbiology and Applied Sciences 6(9): 923-936.

Jackson ML 1973. Soil Chemical Analysis, Prentice Hall of India (P) Ltd., New Delhi.

Jadhao SD, Arjun D, Mali V, Singh M, Kharche VK, Wanjari RH, Kadu PR, Sonune BA and Magare PN 2018. Effect of long term manuring and fertilization on depth wise distribution of potassium fractions under sorghum-wheat cropping sequence in Vertisol. Journal of the Indian Society of Soil Science 66(2): 172-181.

Jassal HS, Kumar R, Singh K and Dhillon NS 2012. Vertical distribution of readily and slowly available potassium in typic Haplustept under different cropping sequences. Indian Journal of Ecology 39(1): 92-97.

Kundu MC, Hazra GC, Biswas PK, Mondal S and Ghosh GK 2014. Forms and distribution of potassium in some soils of Hooghly district of West Bengal. Journal of Crop and Weed 10(2): 31-37.

Received 22 October, 2021; Accepted 19 January, 2022
Lakaria BJ, Behera SK and Singh D 2012. Different forms of potassium and their contributions toward potassium uptake under long-term maize (Zea mays L.) - wheat (Triticum aestivum L.) - cowpea (Vigna unguiculata L.) rotation on an inceptisol. Communications in Soil Science and Plant Analysis 43: 936947.

Lalitha M and Dhakshinamoorthy M 2014. Forms of soil potassium-a review. African Journal of Agricultural Research 35(1): 64-68.

Lungmuana, Bose A, Ghosh I, Ghosh SK and Patra PK 2014. Distribution and variation of potassium in rice growing soils of red and laterite zone of West Bengal. Journal of the Indian Society of Soil Science 62(1): 84-87.

Mali DV, Lokya T, Jadhao SD, Gabhane VV, Kadu PR, Paslawar AN and Sonune BA 2016. Effect of various levels of potassium on potassium fractions under soybean grown on farmer's field in vertisols The Ecoscan 9: 115-119.

Padhan D, Rout PP and Sahoo T 2015. Surface and sub-surface distribution of available potassium in rice growing soils under western central table land agro-climatic zones of Odisha. Journal of Agroecology and Natural Resource Management 2(5): 365-368.

Prasad J 2010. Forms of potassium in shallow soils of different origin and land uses in Nagpur district of Maharastra. Journal of the Indian Society of Soil Science 58(3): 327-330.

Pratt PF 1965. Potassium. In Methods of Soil Analysis Part 2 (C.A. Black, Ed.), American Society of Agronomy Inc., Madison, Wisconsin, pp. 1022-1030.

Rao KN, Yeledhalli NA and Channal HT 2013. Soil potassium dynamics under intensive rice cropping in TBP command area of north Karnataka. An Asian Journal of Soil Science 8(2): 319324.

Rout PP, Chandrasekaran N, Arulmozhiselvan K and Dhaneshwar Padhan 2017. Effect of Long term fertilization on soil K dynamics and uptake by hybrid maize in an irrigated Inceptisol under intensive cropping. International Journal of Current Microbiology and Applied Sciences 6(10): 1049-1061.

Saini J and Grewal KS 2014. Vertical distribution of different forms of potassium and their relationship with different soil properties in some Haryana soil under different crop rotation. Advances in Plants and Agriculture Research 1(2): 48-52.

Sawarkar SD, Khamparia NK, Thakur R, Dewda MS and Singh M 2013. Effect of long-term application of inorganic fertilizers and organic manure on yield, potassium uptake and profile distribution of potassium fractions in Vertisol under soybeanwheat cropping system. Journal of the Indian Society of Soil Science 61: 94-98.

Srinivasarao Ch, Satyanarayana T and Venkateswarlu B (2011) Potassium mining in Indian agriculture: Input and output balance. Karnataka Journal of Agricultural Sciences 24 (1): 20 28.

Tomar PS, Gupta N, Gurjar NS, Verma SK and Bansal KN 2017. Long term effect of fertilizers and manure on K- fractions in inceptisol under pearl millet-mustard cropping system. International Journal of Chemical Studies 5(6): 948-952.

Wani JA, Malik MA, Dar MA, Akhter F and Bhat MA 2012. Forms and quantity-intensity parameters of potassium applied to wheat under temperate conditions of Kashmir. Indian Journal of Ecology 39(1): 98-101.

Wiklander EA 1954. Forms of potassium in the soil. Potassium Symposium. International Potash Institute, Berne, Switzerland, pp. 109-121.

Wood LK and De Turk EE 1941. The adsorption of potassium in soil in non-exchangeable forms. Proceedings of the Soil Science Society of America 5: 152-161. 